Jurnal Ilmiah Ilmu Administrasi

ISSN 2085-1162

\title{
PERLAKUAN PAJAK PERTAMBAHAN NILAI (PPN) ATAS DEBIT NOTE EKSPOR JASA KENA PAJAK
}

\author{
Dian Wahyudin \\ Institut Ilmu Sosial dan Manajemen STIAMI \\ dios ok@yahoo.co.id
}

\begin{abstract}
Abstrak. Penelitian ini bertujuan untuk mengetahui apakah Debit Note merupakan objek PPN dan terutang PPN 10\% (sepuluh persen) atas ekspor jasa kena pajak bila ditinjau dari taxable supplies dan untuk mengetahui perlakuan PPN atas Debit Note ditinjau dari konsep destination principle serta untuk mengetahui apakah diperbolehkan menerbitkan Debit Note dalam peraturan perpajakan untuk menagih penghasilan dan berapa estimasi sanksi yang timbul. Penelitian ini menggunakan metode kualitatif dengan analisis deskriftif kualitatif. Objek penelitian berdasarkan data yang tersedia di dalam perusahaan yang bersifat skunder. Teknik pengumpulan data studi kepustakaan. Hasil pengolahan data menunjukkan bahwa Debit Note ditinjau dari taxable supplies merupakan objek PPN dan terutang PPN 10\% (sepuluh persen). Ditinjau dari destination Principle Debit Note dikenakan PPN 0\% (Nol Persen) untuk shipping charge, Minimum Order Quantity (MOQ) charge dan cancel order charge/penalty fees. Mekanisme penagihan melalui Debit Note diperbolehkan selama ada dokumen yang kedudukannya dipersamakan dengan faktur pajak untuk cancel order charge/penalty fees, tetapi untuk shipping charge dan Minimum Order Quantity (MOQ) charge tidak diperbolehakan dalam peraturan perpajakan karena tidak memenuhi syarat material dari faktur pajak. Akibatnya dari Debit Note yang diterbitkan untuk menagih penghasilan, timbul sanksi pasal 14 ayat (2) UU KUP sebesar 2\% dari dasar penganan pajak. Ini menunjukkan bahwa dalam menerbitkan Debit Note perlu membuat dokumen yang disamakan dengan Faktur Pajak karena penyerahan melalui mekanisme Debit Note tersebut merupakan objek PPN
\end{abstract}

\section{Kata Kunci: PPN, Debit Note}

Abstract. This study was conducted to determine about the debit notes is a taxable and tariffs 10\%( ten percent ) on export of taxable service if it is reviewed by taxable supplies, and to determine the treatment of VAT on Debit Note reviewed by the concept of destination principle and to determine whether it is acceptable in tax regulation of Indonesia if It's issued a Debit Note for collecting of company income and to estimate how much penalties arise. This study used qualitative methods with qualitative descriptive analysis. The object of research is based on data available at the company that is secondary data. Data collection techniques are Library research.The results of data processing that the Debit Note is an taxable of VAT. In terms of destination Principle Debit Note is taxable to VAT $0 \%$ (Zero Percent) for the shipping charge, the Minimum Order Quantity (MOQ) charge and cancel orders charge / penalty fees. Debit Note Billing mechanism is allowed in tax regulation as long as there is a document whose position equivalent to tax invoice for canceled order charge/penalty fees, but charge for shipping and the Minimum Order Quantity (MOQ) charge don't allow in the tax regulation because it is non-compliance of the material terms of the tax invoice. As a result of the Debit Note that issued raised the sanctions of Article 14 paragraph (2) of general provisions and taxation procedures for $2 \%$ of the tax base.

Based on the suggested better in making commercial document to charge must analyze aspects of taxation in order to prevent tax penalties in this case to issue Debit Note need to create a document that is equivalent to a Tax Invoice because mechanism of the Debit Note is taxable of VAT.

Keywords: Value Added Tax, Debit Note

Seiring perkembangan perdagangan internasional baik itu sektor primer (pertambangan, pertanian dan perikanan), sektor sekunder (manufaktur) ataupun sektor tersier (industri jasa). permintaan atas barang dan jasa di negara-negara seluruh dunia 
mengalami peningkatan baik dari segi jumlah maupun jenisnya. Termasuk di Indonesia, aktivitas Indonesia dalam perdagangan internasional selalu mengalami perubahan.
Hal ini dapat dilihat dari fluktuasi jumlah ekspor dan impor Indonesia dari tahun ke tahun yang dapat dilihat dari grafik di bawah ini.

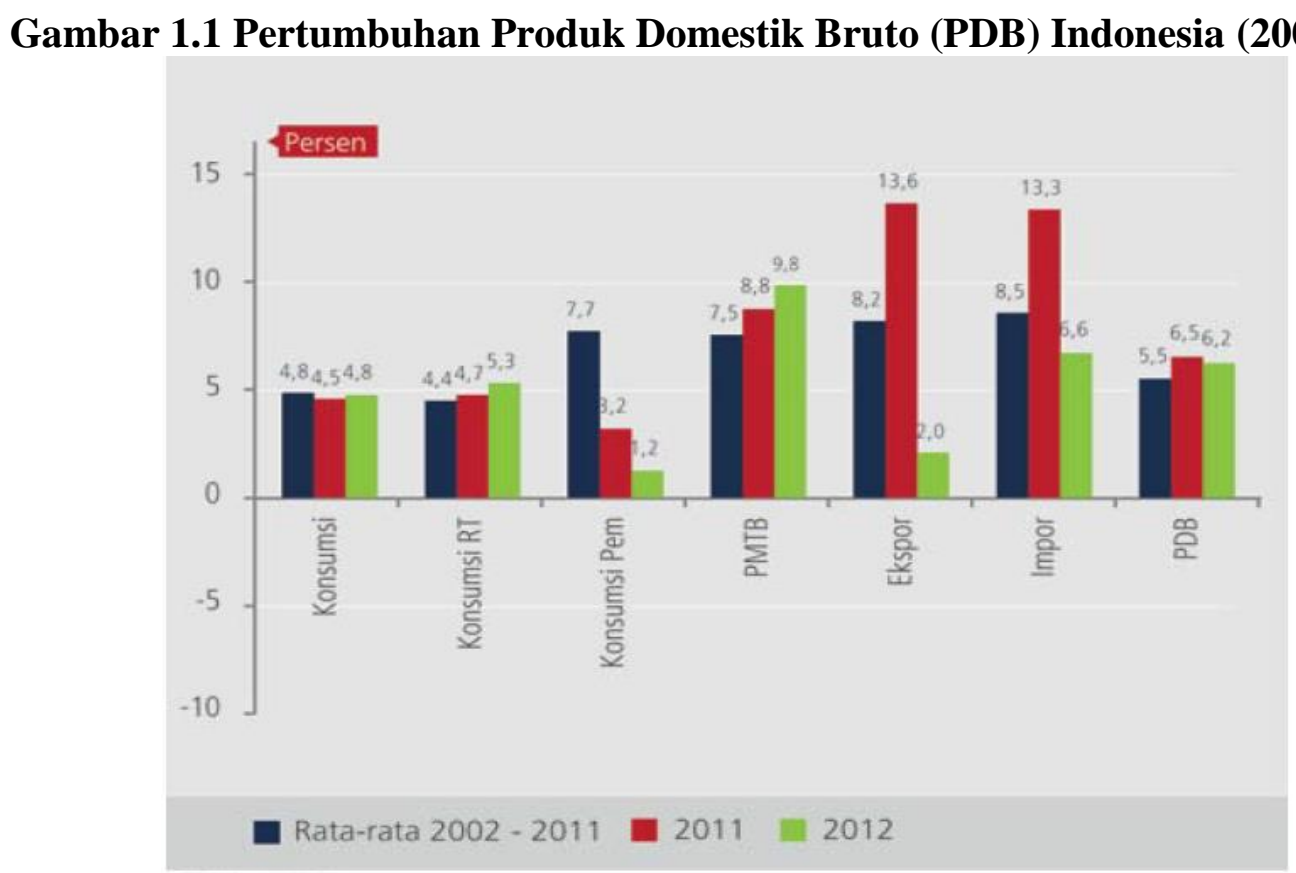

Sumber: Bank Indonesia

Peranan sektor jasa dalam perekonomian suatu negara merupakan salah satu sektor yang pertumbuhannya sangat cepat. Hal ini dikarenakan jasa memberikan infrastruktur yang diperlukan bagi pertumbuhan ekonomi dan pembangunan nasional. Sehigga sektor jasa layak untuk mendapatkan perhatian yang serius dari pemerintah.
Namun, persoalan lama yang masih dihadapi Indonesia mengenai transaksi luar negeri adalah defisit Neraca Perdagangan Jasa. Hal ini dikarenakan Naiknya impor barang yang mengakibatkan tingginya kegiatan pengangkutan impor barang (freight on import). Perkembangan Neraca Perdagangan Jasa Indonesia dapat dilihat pada grafik di bawah ini.

\section{Gambar 1.2 Perkembangan Neraca Perdagangan Jasa Indonesia (2006-2012)}

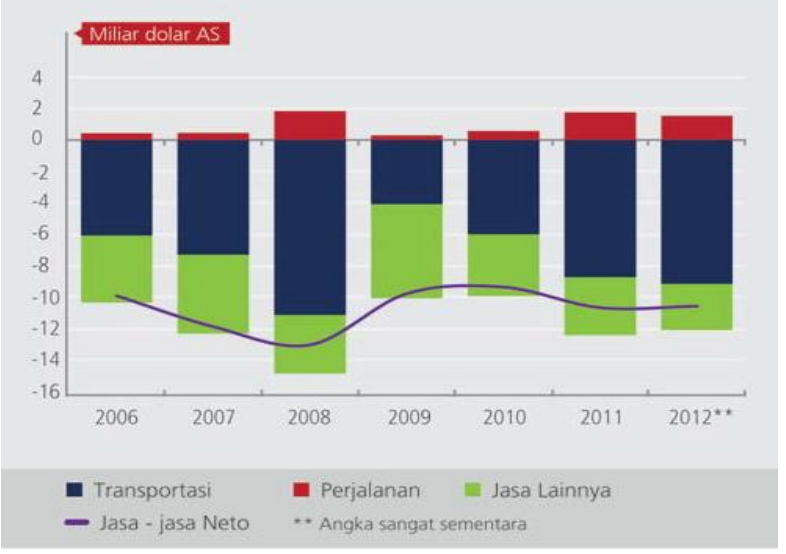

Sumber: Bank Indonesia

Perkembangan perdagangan jasa secara internasional tentu tidak lepas dari aspek perpajakan. Adanya ekspor jasa dan impor jasa dalam perdagangan internasional salah satu konsekuensinya adalah terutang Pajak Pertambahan Nilai (PPN). Dasar hukum pemungutan PPN di Indonesia diatur dalam Undang-Undang 
Nomor 8 Tahun 1983 sebagaimana telah diubah dengan Undang-Undang Nomor 42 Tahun 2009 tentang Pajak Pertambahan Nilai Barang dan Jasa dan Pajak Penjualan atas Barang Mewah (selanjutnya disebut UU PPN). Pemerintah mengatur dalam UU PPN bahwa kegiatan ekspor Jasa Kena Pajak (JKP) dan impor JKP merupakan Objek PPN sebagaimana diatur dalam pasal 4 ayat (1) UU PPN.

Pemerintah memberikan fasilitas pajak untuk ekspor JKP berupa tarif 0\% (nol persen) sebagaimana diatur dalam pasal 7 ayat (2) huruf c. Namun, ketentuan ekspor JKP yang dikenai pajak nol persen tidak berlaku untuk semua ekspor JKP. Batas kegiatan dan jenis JKP yang dikenai PPN dengan tarif nol persen diatur lebih lanjut dalam Peraturan Menteri Keuangan (PMK) Nomor 70/PMK.03/2010 tentang Batasan Kegiatan dan Jenis atas Ekspor Jasa Kena Pajak yang Atas Ekspornya Dikenai PPN sebagaiman diubah terakhir dengan PMK Nomor 30/PMK.03/2011. Pada pasal 4 PMK tersebut diatur bahwa jenis JKP yang atas ekspornya dikenai PPN nol persen adalah jasa maklon, jasa perbaikan dan perawatan dan jasa konstruksi. Sehingga tarif PPN sebesar nol persen hanya dapat diterapkan kepada tiga jenis jasa tersebut.

Perlakuan PPN ini tentu akan menimbulkan masalah dalam perlakuan PPN atas ekspor JKP lainnya, hal ini menyebabkan terjadinya perbedaan persepsi antara fiskus dan wajib pajak sampai menimbulkan terjadi pemeriksaan, dimana fiskus menganggap debit note merupakan objek PPN atas ekspor JKP sebagaimana diatur dalam pasal 4 ayat (1) UU PPN yang harus dibuatkan Pemberitahuan Ekspor Jasa Kena Pajak (PEJ) dan melunasi PPN yang terutang $10 \%$ (sepuluh persen). Sedangkan menurut WP, debit note merupakan Reimbursement atas charge tambahan yang dikenakan kepada WP atas order buyer diluar sales contract, sehingga menurut WP reimbursement tersebut bukan merupakan objek PPN tetapi objek Pajak Penghasilan (PPh).

A. Pokok Permasalahan

1. Apakah debit note yang diterbitkan PT. X merupakan objek PPN dan terutang PPN 10\% (sepuluh persen) sebagaiman pendapat fiskus bahwa Debit Note yang diterbitkan PT. X merupakan Ekspor JKP ditinjau dari taxable supplies?.

2. Bagaimana perlakuan PPN atas Debit Note ditinjau dari konsep destination principle?

B. Tujuan Penelitian

1. Untuk mengetahui apakah debit note yang diterbitkan PT. X merupakan objek PPN dan terutang PPN 10\% (sepuluh persen) sebagaiman pendapat fiskus bahwa Debit Note yang diterbitkan PT. X merupakan Ekspor JKP ditinjau dari taxable supplies.

2. Untuk mengetahui perlakuan PPN atas Debit Note ditinjau dari konsep destination principle.

\section{Tinjauan Pustaka}

\section{Pemahaman Tentang Pajak}

\section{a. Definisi Pajak:}

Banyak para pengamat pajakmemberikan pendapat tentang definisi pajak. Menurut P.J.A. Adriani (Waluyo, 2007:2)

Pajak adalah iuran kepada negara (yang dapat dipaksakan) yang terutang oleh yang wajib membayarnya menurut peraturan-peraturan dengan tidak mendapat prestasi kembali yang langsung dapat ditunjuk, dan yang gunanya adalah untuk membiayai pengeluaranpengeluaran umum berhubungan dengan tugas negara yang menyelenggarakan pemerintahan.

Sedangkan menurut Rachmat Soemitro (Waluyo,2007:1) 
Pajak ialah iuran rakyat kepada negara (peralihan kekayaan dari sektor swasta ke sektor publik) berdasarkan undang-undang yang dapat dipaksakan dengan tidak mendapat imbalan yang secara langsung dapat ditunjukan, yang digunakan sebagai alat pendorong, penghambat atau pencegah untuk mencapai tujuan yang ada dalam bidang keuangan Negara.

Menurut Undang-Undang Nomor 6 Tahun 1983 sebagaimana telah diubah dengan Undang-Undang Nomor 16 Tahun 2009 Tentang Ketentuan Umum Dan Tata Cara Perpajakan pasal 1 angka 1, Pajak adalah kontribusi wajib kepada negara yang terutang oleh orang pribadi atau badan yang bersifat memaksa berdasarkan Undang-Undang, dengan tidak mendapatkan imbalan secara langsung dan digunakan untuk keperluan negara bagi sebesar-besarnya kemakmuran rakyat.

\section{b. Ciri-ciri Pajak}

Dari definisi tersebut di atas, dapat disimpulkan bahwa ciri-ciri yang melekat pada pengertian pajak adalah:

1) Pajak dipungut berdasarkan undangundang serta aturan pelaksanaannya dapat dipaksakan.

2) Dalam pembayaran pajak tidak dapat ditunjukan adanya kontraprestasi langsung individual oleh pemerintah.

3) Pajak dipungut oleh negara baik pemerintah pusat maupun daerah.

4) Pajak diperuntukan bagi pengeluaranpengeluaran pemerintahbagi sebesarbesarnya kemakmuran rakyat.

5) Pajak dapat pula mempunyai fungsi selain budgeter, yaitu mengatur.

\section{Pajak Pertambahan Nilai (PPN)}

a. Pengertian Pajak Pertambahan Nilai

Pengertian Value Added, menurut Alan Tait dalam bukunya Value Added Tax: International Practice and Problems yang dikutip oleh Saraswatiadalah sebagai berikut:
Value Added is the value that a producer (whether a manufacturer, distributor, advertising agent, hairdresser, farmer, race horse trainer or circus owner,) adds to his raw material or purchases (other than labor) before selling the new or improved product or service. That is the inputs (the raw materials, transport, rent advertising and so on) are bought, people are paid wages to work on these inputs and, when the final good and service is sold, some profits is left. So value added can be looked at from the additive side (wages plus profits) or from the subtractive side (output minus inputs) (Saraswati, 2012:23).

Berdasarkan pengertian yang dipaparkan oleh Alan Tait di atas, maka value added dapat dilihat dari dua sisi. Hal tersebut dapat dilihat dan formula di bawah ini:

Value Added $=$ Wages + Profits $=$ Output - Input

Dari pengertian di atas, maka pajak atas pertambahan nilai tersebut dinamakan Value Added Tax.

Menurut Melville dalam bukunya, Value Added Tax (VAT)dikutip oleh Saraswatidinyatakan sebagai:

sebuah pajak tidak langsung yang dikenakan atas penyerahan barang dan jasa, dimana prinsip dasarnya adalah suatu pajak yang harus dikenakan pada setiap proses produksi dan distribusi tetapi jumlah pajak yang terutang dibebankan kepada konsumen akhir yang memakai produk tersebut (Saraswati, 2012:24).

Smith dkkseperti yang dikutip oleh Rosdiana \& Tarigan (2005: 215).mendefinisikanValue Added Tax (VAT) sebagai berikut:

The VAT is tax on the value added by a firm to its products in the course of its operation. Value Added can be viewed either as the difference between a firms, sales and its purchase during an accounting period or as the Sum of its wages, profits, rent, interest and 
other payments not subject to the tax during that period.

Berdasarkan pengertian yang dikemukakan oleh Smith dkk, VAT dapat dilihat sebagai selisih antarapenjualan dan pembelian yang dilakukan oleh sebuah perusahaan dalam suatu periode akuntansi tertentu.

\section{b. Karakteristik Pajak Pertambahan Niali}

Legal character dari PPN secara umurn yang dikemukakan oleh Rosdiana, Irianto, dan Putrantidapat digambarkan sebagai berikut,

\section{1) General tax}

PPN merupakan pajak atas konsumsi yang bersifat umum.Pengertian secara umum ini untuk membedakan PPN dengan pajak atas konsumsi secara khusus, yaitu cukai.PPN merupakan pajak yang bersifat umum karena ditujukan untuk semua pengeluaran masyarakat secara keseluruhan, tanpa membedakan pengeluaran tersebut berupa barang atau jasa, yang terpenting pengeluaran tersebut adalah untuk konsumsi.

Dikutip oleh Rosdiana, Irianto, dan Putranti dalam buku Teori Pajak Pertambahan Nilai, " $a$ sales tax is a general tax on consumption", artinya bahwa PPN merupakan pajak atas konsumsi yang bersifat umum, yang dikenakan pada semua pengeluara privat.Sebagai konsekuensinya maka tidak boleh ada diskriminasi. (Rosdiana, Irianto, dan Putranti, 2011:44)

\section{2) Indirect tax}

PPN merupakan salah satu pajak tidak langsung (indirect tax). Pajak tidak Iangsung dapat diartikan sebagai pajak yang tidak dibebankan secara langsung kepada satu pihak, tetapi dapat dialihkan kepada pihak lain. Peralihan pajak ini dapat berbentuk forward shifting, yaitu peralihan pajak ke saluran distribusi.selanjutnya sampai dengan konsumen yang menjadi sasaran akhir pajak.Peralihan semacam inilah yang membedakan indirect tax dengan direct tax. Pajak tidak langsung ditanggung oleh konsumen, tetapi yang memungut, menyetorkan, dan melaporkan pajak yang terutang adalah Pengusaha Kena Pajak (Rosdiana, Irianto, dan Putranti, 2011:47)

Pada pajak Iangsung akan berlangsung shifting backward, dimana pajak akan ditanggung oleh produsen dan tidak akan mempengaruhi harga jual konsurnen. Tetapi pajak tidak Iangsung akan dilakukan shifling forward, dimana pajak akan dialihkan pada konsumen.

\section{3) On Consumption}

Pajak Pertambahan Nilai merupakan pajak atas konsumsi (tax on consumption).Konsumsi yangdimaksudkan adalah pengeluaran yang dilakukan, tanpa membedakan apakah konsumsi tersebut digunakan sekaligus maupun digunakan secara bertahap.Dalam pengertian konsumsi, baik barang berwujud maupun barang tidak berwujud serta jasa.Sebagal pajak atas konsumsi maka PPN dikenakan terhadap penyerahan dalam negeri dan juga impor (Rosdiana, Irianto, dan Putranti, 2011:59).

\section{4) Non cumulative}

PPN merupakan pajak yang tidak bersifat kumulatif karena dikenakan atas nilai tambah.Hal ini menjadi kelebihan PPN dibandingkan dengan pajak penjualan.Tidak bersifat kumulatifnya PPN dikarenakan adanya sistem pengkreditan, sehingga pajak di mata rantai sebelumnya tidak dikalkulisasikan ke dalarn harga jual(Saraswati, 2012: 24).

\section{c. Yuridiksi Pajak Pertambahan Nilai}

Dalam teori pajak atas lalu lintas barang dan jasa, terdapat dua prinsip yuridiksi atau kewenangan pemungutan pajak, yaitu prinsip asal tempat barang (origin principle) dan prinsip tujuan (destination principle) (Rosdiana dan Tarigan, 2005:148).

1) Prinsip asal tempat barang (origin principle) 
Menurut Ben Terra, dalam prinsip asal tempat barang (origin principle). negara yang berhak mengenakan pajak adalah negara dimana barang diproduksi atau dimana barang tersebut berasal. Berdasarkan prinsip ini seluruh barang dan jasa yang diproduksi di dalam suatu negara akan dikenakan Pajak Pertambahan Nilai oleh negara tersebut, tanpa memperhatikan apakah dikonsumsi di negara tersebut atau di luar negara tersebut (diekspor). Konsekuensi dan penggunaan prinsip ini adalah secara tidak Iangsung meningkatkan biaya penjualan ekspor (Consequently this type of tax indirectly increases the cost of export sales).

Originprinciple juga

dikemukakan oleh beberapa ahli perpajakan yang lain antara lain Gillis berpendapat bahwa suatu Pajak Pertambahan Nilai dikatakan menggunakan prinsip asal tempat barang (origin principle) bila PPN tersebut dikenakan atas seluruh barangbarang yang diproduksi di dalam negeri, termasuk barang-barang yang selanjutnya diekspor, tetapi tidak dikenakan atas seluruh barang-barang yang diproduksi di dalam negeri, termasuk bararig-barang yang selanjutnya diekspor, tetapi tidak dikenakan atas barang-barang yang diproduksi di luar negeri yang diimpor dan dijual di dalam negerisebagaiman menurut Gillis, Shoup, \& Sicat dalam bukunya yang berjudulVAT in Developing Countries yang dikutip oleh Saraswati:

a VAT is said to use the origin principle when it taxes value that is added domestically to all goods, including goods that are subsequently exported, but does not tax value that has been added abroad and is embodied in foods that are imported and sold domestically (Saraswati, 2012: 27).

Selain itu Alan Tait menyatakan yang dikutip oleh Saraswatibahwa dalam prinsip asal tempat barang (origin principle). Pajak Pertambahan
Nilai dibebankan atas pertambahan nilai (value added) yang dihasilkan dari kegiatan bisnis yang ada di dalam kewenangan pemajakan (the taxing jurisdiction), tanpa memperhatikan dimana barang-barang tersebut dikonsumsi. PPN tidak dikenakan atas impor, tetapi dikenakan atas ekspor.

A VAT must include jurisdictional rules governing international transactions. The Jurisdictional rules may be based on the origin or the destination principle. Under the origin principle, tax is imposed on value added from business activity within the taxing jurisdiction, regardless, of where the goods are consumed. VA $T$ is not imposed on imports, nor is it rebated on exports (Saraswati, 2012: 27).

2) $\begin{aligned} & \text { Prinsip } \\ & \text { principle) } \\ & \text { Menurut }\end{aligned}$
Ben bukunya Sales Taxation: The case of Value Added Tax in The European Community yang dikutip oleh Saraswati, berdasarkan prinsip tujuan (destination principle), negara yang berhak mengenakan pajak adalah negara dimana barang tersebut dikonsumsi. Jika barang diimpor maka akan kena pajak. tetapi jika barang diekspor maka tidak akan dikenakan pajak . Prinsip tujuan yang dikemukakan oleh Ben Terra di atas, sejalan dengan pendapat beberapa ahli perpajakan antara lain Gulls menyatakan hahwa berdasarkan prinsip tujuan, PPN dikenakan oleh Negara tempat konsumsi barang-barang. "It taxes all value added, at home and abroad, to all goods that as their destination the consumers of that country"'(Saraswati, 2012: 28)

Selain itu Alan Tait menyatakan
bahwa seluruh sistem Pajak Pertambahan Nilai saat ini didasarkan pada prinsip tujuan (destination principle), yaitu pada garis perbatasan fiskal (fiscal frontiers) harus diyakinkan bahwa atas ekspor tidak dikenakan Pajak Pertambahan Nilai secara penuh, 
artinya tidak dikenakan Pajak Pertambahan Nilai dan tidak mengandung nilai Pajak Pertambahan Nilai yang dibayar di dalam negeri, dan Pajak Pertambahan Nilai dikenakan atas impor.

All present VAT Systems are based on the destination principle, where fiscal frontiers must be maintain to ensure that exports are fully rebated for the VAT paid in the exporter's domestic market and where the VAT rates appropriate to the importer's home market can be applied (Saraswati, 2012: 28).

Selanjutnya Alan Schenk dalam bukunya Value Added Tax: a Comparative Approach yang dikutip oleh Saraswati menyatakan bahwa berdasarkan prinsip tujuan, Pajak Pertambahan Nilai dikenakan atas barang-barang dan jasa yang dikonsumsi di dalam Daerah Pabean (taxing jurisdiction), tanpa memperhatikan dimana barang dan jasa tersebut diproduksi. PPN dikenakan atas impor untuk konsumsi di dalam negeri dan tidak dikenakan atas ekspor untuk dikonsuinsi di negara lain.

Under the destination principle, VAT is imposed on goods and services consumed in the taxing jurisdiction, regardless of where they are produce. $V A T$ is imposed on imports for consumption in tile United States, and VAT is rebated on exports to be consumed elsewhere (Saraswati, 2012: 28).

Berdasarkan prinsip ini negara yang berhak mengenakan PPN adalah negara dirnana barang dan/atau jasa tersebut dikonsumsi, termasuk atas barang dan /atau jasa yang diproduksi di luar negeri yang diimpor dan dikonsumsi di dalam negeri. Sebaliknya jika barang dan/atau jasa diekspor maka tidak akan dikenal PPN. Hal tersehut seperti yang diungkapkan oleb Scheck dan Oldman yang dikuitp oleh Saraswati (2012: 28), "Under a pure destination principle, VAT is imposed on imports and rebated on exports".
Hampir seluruh negara saat ini menggunakan destination principle karena Iebih netral untuk perdagangan internasional.Hal ini dilakukan dalam rangka harmonisasi perpajakan demi terciptanya suatu iklim perdagangan internasional yang fair dan netral. Letak perbedaan antara origin principle dengan destination principle adalah pada:

a) Treatment antara impor dan ekspor, seperti yang dijelaskan oleh Howell dalam tulisannya "Value Added Tax":

Exports are taxed hut imports are not under the origin principle, while just the converse holds under the destination principle Saraswati (2012: 28).

b) Lokasi produksi dan konsumsi. seperti yang juga dijelaskan oleh Howell:

It is importulit to note the distinction between the two principles based on the location of production and consumption Saraswati (2012: 28).

\section{Ekspor Jasa Kena Pajak}

dalam buku Teori Pajak Pertambahan Nilai Rosdiana, Irianto, Putranti (2011: 100) Berdasarkan pasal 1 angka angka 29 UU PPN: "Ekspor Jasa Kena Pajak adalah setiap kegiatan penyerahan jasa kena pajak ke luar daerah pabean". Yang dimaksud dengan Daerah Pabean adalah wilayah Republik Indonesia yang meliputi wilayah darat, perairan, dan ruang udara diatasnya, serta tempat-tempat tertentu di Zona Ekonomi Eksklusif dan landas kontinen yang di dalamnya berlaku Undang-Undang nomor 10 tahun 1995 sebagaimana telah diubah dengan Undang-Undang Nomor 17 Tahun 2006 Tentang Kepabeanan

\section{Debit Note}


Debit note adalahadalah commercial document yang diterbitkan oleh pembeli kepada penjual sebagai sarana formal meminta nota kredit.Seorangpenjual dapat juga menerbitkan nota debet bukan sebuah invoice untuk menyesuaikan atas jumlah nilai diinvoice yang sudah diterbitkan (invoice salah).

A debit note or debit memorandum (memo) is a commercial document issued by a buyer to a seller as a means of formally requesting a credit note. A seller might also issue a debit note instead of an invoice in order to adjust upwards the amount of an invoice already issued (as if the invoice is recorded in wrong value) (www.wikipedia.org).

\section{Strategi Analisis Data}

\section{Penafsiran Debit Note}

\section{Menurut Pendapat FIskus}

Debit note digabung pada saat penagihan menggunakan commercial invoice dan di Pemberitahuan Ekspor (PEB) Barang, karena PPN dikenakan atas nilai penggantian (nilai seharusnya diminta) bukan hanya dari harga jual. Adanya pelepasan hak penagihan oleh Wajib Pajak dan jasa penalangan yang dilakukan Wajib Pajak atas beban yang dibayar dahulu untuk kepentingan pembeli. Sehingga menurut fiskus transaksi Wajib Pajak atas debit note merupakan objek Pajak Pertambahan Nilai (PPN).

\section{Menurut Pendapat Wajib Pajak}

$$
\text { Debit note merupakan }
$$

reimbursement atas charge tambahan yang dikenakan kepada WP atas order buyer diluar trading contract, sehingga menurut WP reimbursement tersebut bukan merupakan objek PPN tetapi objek Pajak Penghasilan (PPh). Adapun jenis Debit Note yang diterbitkan oleh PT. $X$ ada tiga jenis:
1) Tagihan Debit Note Atas Pembatalan Order (cancelled charge) oleh Buyer. PT X menerbitkan Debit Note kepada buyer atas liability yang timbul karena pembatalan order atau penundaan pengiriman barang jadi. Debit note tersebut adalah claim atas order yang dibatalkan yang dihitung berdasarkan charge dibawah ini:

a) Bahan baku yang di order ke supplier, namun supplier belum kirim ke PT X (masih di gudang supplier), karena sudah di produksi oleh supplier, maka PT $\mathrm{X}$ wajib membayar kerugian atas order bahan baku yang di batalkan tersebut.

b) Bahan baku yang di order ke supplier, supplier sudah mengirimkan ke gudang PT X, namun belum terjadi proses produksi.

c) Bahan baku yang di order ke supplier, supplier sudah mengirimkan ke gudang PT X, dan sudah terjadi proses produksi sebagian atau seluruhnya.

2) Tagihan Debit Note atas selisih biaya pengiriman (shipping charge) ekspor produk dimana berdasarkan trading contract pengiriman melalui jalur laut karena kondisi tertentu sehingga pengiriman mengharuskan melalui jalur udara, maka atas selisih biaya pengiriman PT. $X$ tagih dengan menerbitkan Debit Note.

3) Tagihan Debit Note atas tambahan biaya yang dikenakan supplier kepada PT. X karena Minimum Order Quantity (MOQ charge) bahan baku atas order buyer merupakan tanggung jawab buyer.

\section{B. Analisis Dan Interpretasi Penelitian}

Berdasarkan data yang penulis peroleh maka analisis perlakuan PPN 
atas Debit Note pada PT. X tahun 2012 adalah sebagai berikut:

1. Ditinjau dari taxable supplies

Debit Note telah memenuhi

legal character PPN sehingga

secara merupakan Objek PPN sebagaimana diuraikan dalam table berikut:

Tabel 4.5 Legal Character PPN atas Debit Note PT. X Tahun 2012

\begin{tabular}{|l|c|c|c|l|}
\hline & Cancell Order & MOQ & Shipment Cost & \multicolumn{1}{|c|}{ Keterangan } \\
\hline \hline General tax & $\sqrt{ }$ & $\mathrm{v}$ & $\mathrm{v}$ & $\begin{array}{l}\text { PPN diatur dengan UU sehingga berlaku } \\
\text { secara umum }\end{array}$ \\
\hline Indirect tax & $\mathrm{v}$ & $\mathrm{v}$ & $\mathrm{v}$ & $\begin{array}{l}\text { Dapat dialihkan kepada konsumen } \\
\text { akhir }\end{array}$ \\
\hline On Consumption & $\mathrm{v}$ & $\mathrm{v}$ & $\mathrm{v}$ & $\begin{array}{l}\text { PPN dikenakan atas seluruh konsumsi } \\
\text { BKP/JKP }\end{array}$ \\
\hline Non cumulative & $\mathrm{v}$ & $\mathrm{v}$ & $\mathrm{v}$ & $\begin{array}{l}\text { Adanya metode Pengkreditan PPN } \\
\text { dalam menentukan Utang PPN }\end{array}$ \\
\hline
\end{tabular}

Sumber: Olah Data Penulis

Jika Ditinjau dari taxable supplies berdasarkan peraturan perundangundangan pajak di Indonesia, maka atas transaksi Debit Note diatur sebagai berikut:

a. Cancelled Order Charger (penalty fees)

Berdasarkan Undang-undang Nomor 8 Tahun 1983 tentang Pajak Pertambahan Nilai Barang dan Jasa dan Pajak Penjualan atas Barang Mewah sebagaimana telah diubah terakhir dengan Undang-undang Nomor 42 Tahun 2009 yang selanjutnya disebut UU PPN, antara lain mengatur:

1) Pasal 1 angka 5, bahwa Jasa adalah setiap kegiatan pelayanan yang berdasarkan suatu perikatan atau perbuatan hukum yang menyebabkan suatu barang, fasilitas, kemudahan atau hak tersedia untuk dipakai, termasuk jasa yang dilakukan untuk menghasilkan barang karena pesanan atau permintaan dengan bahan dan atas petunjuk dari pemesan.

2) Pasal 1 angka 6, bahwa Jasa Kena Pajak adalah jasa sebagaimana dimaksud dalam pasal 1 angka 5 yang dikenakan pajak berdasarkan Undang-undang ini.

3) Pasal 1 angka 17, bahwa Dasar Pengenaan Pajak adalah jumlah Harga Jual, Penggantian, Nilai Impor, Nilai Ekspor, atau Nilai Lain yang ditetapkan dengan Peraturan Menteri Keuangan yang dipakai sebagai dasar untuk menghitung pajak yang terutang.

4) Pasal 1 angka 19, bahwa Penggantian adalah nilai berupa uang, termasuk semua biaya yang diminta atau seharusnya diminta oleh pengusaha karena penyerahan Jasa Kena Pajak, ekspor Jasa Kena Pajak, atau ekspor Barang Kena Pajak Tidak Berwujud, tetapi tidak termasuk Pajak Pertambahan Nilai yang dipungut menurut UndangUndang ini dan potongan harga yang dicantumkan dalam Faktur Pajak, atau nilai berupa uang yang dibayar atau seharusnya dibayar oleh Penerima Jasa karena pemanfaatan Jasa Kena Pajak dan/atau oleh penerima manfaat Barang Kena Pajak Tidak Berwujud karena pemanfaatan Barang Kena Pajak Tidak Berwujud dari luar Daerah Pabean di dalam Daerah Pabean. 
5) Pasal 4 huruf h, bahwa Objek PPN salah satunya adalah ekspor Jasa Kena Pajak oleh Pengusaha Kena Pajak.

6) Pasal 4A ayat (3) menetapkan jenis-jenis jasa yang tidak dikenakan Pajak Pertambahan canceled order tidak termasuk kedalam jenis jasa yang tidak dikenakan PPN.

Berdasarkan ketentuan pada uraian diatas, penulis berpendapat bahwa atas pembayaran Cancel Order (penalty fees) merupakan Objek PPN atas ekspor JKP mengingat dalam pembayaran tersebut termasuk nilai penggantian atas biaya-biaya yang dikeluarkan sehubungan dengan penyerahan barang/jasa yang akan diserahkan kepada buyer hal ini sejalan dengan PT. X menerbitkan Debit Note untuk menagih kepada buyer atas cancel order yang supplier bebankan pada PT. X akibat dari pembatalan order oleh buyer berarti adanya pelepasan haknya untuk menggugat atau mengklaim kompensasi, reimbursement kerusakan dan kerugian akibat cancelled order.

\section{b. Shipping Charge}

Berdasarkan UU PPN, antara lain mengatur:

1) Pasal 1 angka 2, bahwa barang adalah barang berwujud, yang menurut sifat atau hukumnya dapat berupa barang bergerak atau barang tidak bergerak, dan barang tidak berwujud..

2) Pasal 1 angka 3, bahwa barang Kena Pajak adalah barang sebagaimana dimaksud dalam pasal 1 angka 2 yang dikenakan pajak berdasarkan Undang-undang ini.
3) Pasal 1 angka 11, bahwa ekspor barang kena pajak berwujud adalah setiap kegiatan mengeluarkan Barang Kena Pajak Berwujud dari dalam Daerah Pabean ke luar Daerah Pabean

4) Pasal 1 angka 17, bahwa Dasar Pengenaan Pajak adalah jumlah Harga Jual, Penggantian, Nilai Impor, Nilai Ekspor, atau Nilai Lain yang ditetapkan dengan Peraturan Menteri Keuangan yang dipakai sebagai dasar untuk menghitung pajak yang terutang.

5) Pasal 1 angka 26, bahwa Nilai Ekspor adalah nilai berupa uang, termasuk semua biaya yang diminta atau seharusnya diminta oleh eksportir.

6) Pasal 4 huruf f, bahwa Objek PPN salah satunya adalah ekspor Barang Kena Pajak Berwujud oleh Pengusaha Kena Pajak.

Berdasarkan ketentuan pada uraian diatas, penulis berpendapat bahwa atas pembayaran shipping charge merupakan Objek PPN yang merupakan kesatuan dengan ekspor BKP berwujud mengingat dalam pembayaran tersebut termasuk nilai ekspor nilai berupa uang, termasuk semua biaya yang diminta atau seharusnya diminta oleh eksportir. Sehingga seharusnya shipping charge merupakan kesatuan menjadi nilai ekspor di Pemberitahuan Ekspor Barang (PEB).

\section{c. MOQ Charge}

MOQ charge merupakan kesatuan dari pembelian sehingga MOQ merupakan bagian dari harga pokok penjualan. Jika di ilustrasikan maka MOQ sebagai berikut: 


\section{Gambar 4.1 : Ilustrasi Posting Biaya}

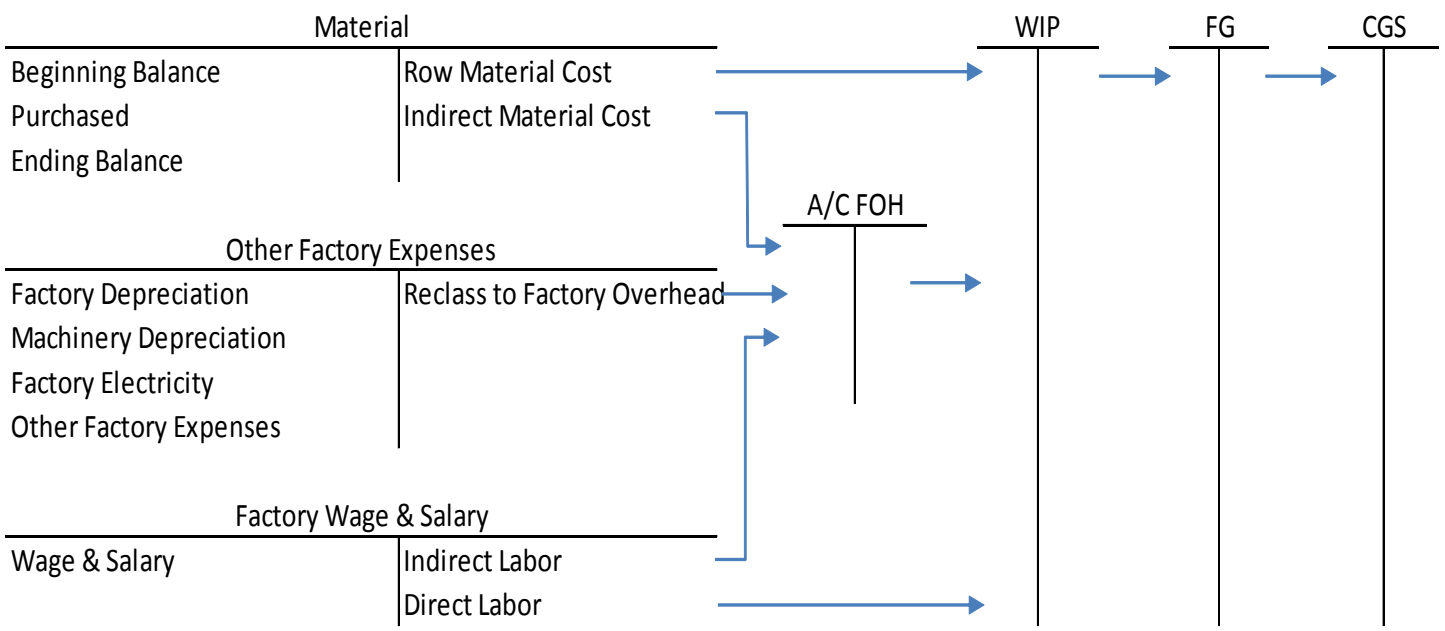

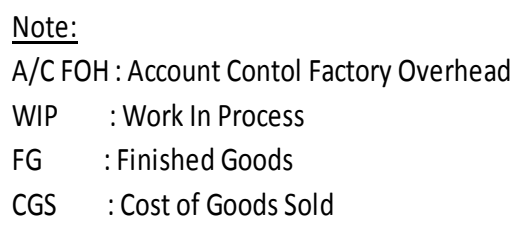

Sumber: Olah Data Penulis

Berdasarkan uraian diatas, penulis berpendapat bahwa atas pembayaran MOQ charger merupakan Objek PPN atas ekspor BKP berwujud mengingat MOQ charger merupakan bagian dari harga pokok penjualan sehingga seharusnya MOQ merupakan kesatuan dengan harga jual/FOB dan ditagih dengan menaikan harga jual/FOB dan di laporkan dalam PEB.

\section{Ditinjau dari destination Principle}

Berdasarkan pendapat Menurut Ben Terra dalam bukunya Sales Taxation: The case of Value Added Tax in The European Community dan sejalan dengan pendapat Gulls, Scheck dan Oldman ataupun Alan Tait dalam bukunya Value Added Tax: a Comparative Approach berdasarkan prinsip tujuan (destination principle), negara yang berhak mengenakan pajak dalam hal ini PPN adalah negara dimana barang tersebut dikonsumsi dalam Daerah Pabean (taxing jurisdiction), tanpa memperhatikan dimana barang dan jasa tersebut diproduksi. Jika barang diimpor maka akan kena pajak. tetapi jika barang diekspor maka tidak akan dikenakan pajak atau dikenakan pajak namun dengan tarif
0\%. Hampir seluruh negara saat ini menggunakan destination principle karena Iebih netral untuk perdagangan internasional (cross border transaction). Hal ini dilakukan dalam rangka harmonisasi perpajakan demi terciptanya suatu iklim perdagangan internasional yang fair dan netral.

Jika ditinjau dari destination Principle berdasarkan ketentuan peraturan perundang-undangan pajak di Indonesia, maka atas transaksi Debit Note diatur sebagai berikut:

\section{a. Cancelled Order Charger (penalty fees) \\ Cancel Order (penalty fees)} merupakan Objek PPN atas ekspor JKP. Ketentuan Ekspor JKP Menurut UU PPN Pasal 4 ayat (1) huruf h UU PPN menyatakan bahwa Pajak Pertambahan Nilai (PPN) dikenakan atas kegiatan ekspor JKP oleh pengusaha kena pajak. Dalam memori penjelasannya ditegaskan bahwa termasuk dalam pengertian ekspor JKP adalah penyerahan JKP dari dalam Daerah Pabean ke luar Daerah Pabean oleh PKP yang menghasilkan dan melakukan ekspor BKP berwujud atas 
dasar pesanan atau permintaan dengan bahan dan atas petunjuk dari pemesan di luar Daerah Pabean.

Kemudian berdasarkan Pasal 7 ayat (2), UU PPN menegaskan bahwa tarif PPN atas ekspor JKP ditetapkan sebesar 0\%. Karena menurut penjelasan UU PPN, yang ada di memori penjelasan Pasal 4 ayat (2), pengenaan PPN 0\% (nol persen) itu dikarenakan PPN secara prinsip adalah pajak yang dikenakan atas konsumsi Barang Kena Pajak (BKP) di dalam Daerah Pabean. Dan berhubung terhadap dalam konteks ekspor JKP konsumsi JKPnya terjadi di luar Daerah Pabean, itulah sebabnya PPN yang dikenakan nol persen (destination principle).

Tetapi Menteri Keuangan yang diberikan kewenangan oleh Pasal 4 ayat (2) UU PPN untuk menetapkan batasan kegiatan dan jenis JKP yang atas ekspornya dikenai PPN tersebut, kemudian menerbitkan Peraturan Menteri Keuangan (PMK) Nomor 70/PMK.03/2010 sebagaimana telah diubah terakhir dengan 30/PMK.03/2011.PMK ini ternyata hanya menetapkan 3 (tiga) jenis JKP yang atas ekspornya dikenai PPN sebagaimana dimaksud Pasal 4 ayat (1) huruf h UU PPN. Ketiga jenis JKP tersebut adalah:

1. Jasa maklon, dengan syarat pemesan atau penerima jasa berada di luar Daerah Pabean dan merupakan Wajib Pajak luar negeri serta tidak mempunyai BUT di Indonesia;

2. Jasa perawatan dan perbaikan atas barang bergerak yang dimanfaatkan di luar Daerah Pabean; dan

3. Jasa konstruksi, yang meliputi jasa perencanaan, jasa pelaksanaan dan jasa pengawasan pekerjaan konstruksi, yang proyek konstruksinya terletak di luar Daerah Pabean.

Berdasarkan Peraturan Pemerintah (PP) Nomor 1 Tahun 2012. Dalam Pasal 6, PP Nomor 1 Tahun 2012 itu menyatakan bahwa PPN dikenakan atas penyerahan JKP di dalam Daerah Pabean yang dilakukan oleh pengusaha yang dimanfaatkan di dalam atau di luar Daerah Pabean. Dalam memori penjelasannya PP tersebut menyatakan bahwa menurut memori penjelasan Pasal 4 ayat (1) huruf c UU PPN, pengenaan PPN tidak mensyaratkan apakah jasa harus dikonsumsi atau dimanfaatkan di dalam atau di luar Daerah Pabean. Sehingga berdasarkan PMK No. 30/PMK.03/2012 dan PP No. 1 Tahun 2012 ada ketentuan lain yang harus terpenuhi agar ekspor JKP menganut destination principle. Terakhir ditegaskan Direktur Jenderal Pajak Republik Indonesia Surat Edaran Direktur Jenderal Pajak Nomor SE - 49/PJ/2011 tentang Penyampaian Peraturan Menteri Keuangan Nomor 30/PMK.03/2011 Tentang Perubahan Atas Peraturan Menteri Keuangan Nomor 70/PMK.03/2010 Tentang Batasan Kegiatan Dan Jenis Jasa Kena Pajak Yang Atas Ekspornya Dikenai Pajak Pertambahan Nilai dalam poin 3 huruf $b$ menjelaskan bahwa apabila jasa kena pajak tersebut dilakukan di luar daerah pabean, atasnya tidak terutang pajak pertambahan nilai karena di luar cakupan undang-undang pajak pertambahan nilai hal ini jelas bahwa selama tidak ada penyerahan di dalam daerah pabean maka akan ekspor JKP akan menggunakan destination principle.

Sehingga berdasarkan uraian diatas maka atas ekspor JKP berupa Cancelled Order Charger (penalty fees) merupakan objek PPN yang dikenakan tarif $0 \%$ (nol persen) dan menganut destination principle. Hal ini dikarenakan tidak ada penyerahan di dalam daerah pabean karena berupa pelepasan haknya untuk menggugat atau mengklaim kompensasi, reimbursement kerusakan dan kerugian akibat cancelled order kepada buyer di luar daerah pabean sebagaimana dimaksud pasal 6 PP No. 1 Tahun 2012.

\section{b. Shipping Charge}

shipping charge merupakan Objek PPN, hal ini dikarenakan shiping charge merupakan kesatuan dengan ekspor BKP. Sehingga mengacu pada pasal 7 ayat (2) 
dikenakan $0 \%$ (nol persen) dan menganut destination principle.

\section{c. MOQ Charge}

$M O Q$ charge merupakan Objek PPN, hal ini dikarenakan MOQ charge merupakan bagian dari pembelian bahan baku yang merupakan bagian dari harga pokok penjualan sehingga seharusnya tagihannya menjadi kesatuan dengan ekspor BKP. Sehingga mengacu pada pasal 7 ayat (2) dikenakan $0 \%$ (nol persen) dan menganut destination principle.

\section{Simpulan}

Dari hasil analisis dan penjelasan yang telah dikemukakan pada bab-bab sebelumnya, dapat disimpulkan bahwa:

1. Ditinjau dari taxable supplies karena penyerahan telah memenuhi legal character PPN dan berdasarkan Undangundang Nomor 8 Tahun 1983 tentang Pajak Pertambahan Nilai Barang dan Jasa dan Pajak Penjualan atas Barang Mewah sebagaimana telah diubah terakhir dengan Undang-undang Nomor 42 Tahun 2009 yang selanjutnya disebut UU PPN, maka perlakuan PPN atas Debit note adalah sebagai berikut:

a. Cancelled Order Charger (penalty fees)

Penulis berpendapat bahwa atas pembayaran Cancel Order (penalty fees) merupakan Objek PPN atas ekspor JKP berdasarkan Pasal 4 huruf h UU PPN dan tidak termasuk yang dikecualikan dari jasa yang dikecualikan dari pengenaan PPN sebagaimana diatur Pasal 4A ayat (3) UU PPN, mengingat dalam pembayaran tersebut termasuk nilai penggantian atas biaya-biaya yang dikeluarkan sehubungan dengan penyerahan barang/jasa yang akan diserahkan kepada buyer hal ini sejalan dengan PT. X menerbitkan Debit Note untuk menagih kepada buyer atas cancel order yang supplier bebankan pada PT. X akibat dari pembatalan order oleh buyer berarti adanya pelepasan haknya untuk menggugat atau mengklaim kompensasi, reimbursement kerusakan dan kerugian akibat cancelled order.

b. Shipping Charge
Penulis berpendapat bahwa atas pembayaran shipping charge merupakan Objek PPN yang merupakan kesatuan dengan ekspor BKP berwujud Pasal 4 huruf $f$ UU PPN, mengingat dalam pembayaran tersebut termasuk nilai ekspor nilai berupa uang, termasuk semua biaya yang diminta atau seharusnya diminta oleh eksportir sebagaimana diatur dalam Pasal 1 angka 26. Sehingga seharusnya shipping charge merupakan kesatuan menjadi nilai ekspor di Pemberitahuan Ekspor Barang (PEB).

\section{c. MOQ Charge}

penulis berpendapat bahwa atas pembayaran $M O Q$ charger merupakan Objek PPN atas ekspor BKP berwujud Pasal 4 huruf $f$ UU PPN, mengingat MOQ charger merupakan bagian dari harga pokok penjualan sehingga seharusnya MOQ merupakan kesatuan dengan harga jual/FOB dan ditagih dengan menaikan harga jual/FOB dan di laporkan dalam PEB sebagaimana diatur dalam Pasal 1 angka 26.

2. Ditinjau dari destination Principle maka perlakuan PPN atas Debit note adalah sebagai berikut:

a. Cancelled Order Charger (penalty fees)

Atas ekspor JKP berupa Cancelled Order Charger (penalty fees) merupakan objek PPN yang dikenakan tarif $0 \%$ (nol persen) dan menganut destination principle. Hal ini dikarenakan tidak ada penyerahan di dalam daerah pabean karena berupa pelepasan haknya untuk menggugat atau mengklaim kompensasi, reimbursement kerusakan dan kerugian akibat cancelled order kepada buyer di luar daerah pabean sebagaimana dimaksud pasal 6 PP No. 1 Tahun 2012

b. Shipping Charge

shipping charge merupakan Objek PPN, hal ini dikarenakan shiping charge merupakan kesatuan dengan ekspor BKP. Sehingga mengacu pada pasal 7 ayat (2) 
Jurnal Ilmiah Ilmu Administrasi

ISSN 2085-1162

dikenakan $0 \%$ (nol persen) dan menganut destination principle.

c. MOQ Charge $M O Q$ charge merupakan Objek PPN, hal ini dikarenakan MOQ charge merupakan bagian dari pembelian bahan baku yang merupakan bagian dari harga pokok penjualan sehingga seharusnya tagihannya menjadi kesatuan dengan ekspor BKP. Sehingga mengacu pada pasal 7 ayat (2) dikenakan $0 \%$ (nol persen) dan menganut destination principle. 